MaRBLE Research Papers | Edition 2016 | Volume III

\title{
5 A test for a young democracy: How the RAF challenged the German Rechtsstaat
}

Caroline Gröne and Konrad Duffy

\subsection{Introduction}

When Edward Snowden revealed to which extent modern surveillance systems control the world, this provoked a massive outcry among politicians and citizens. The National Security Agency's (NSA) programme, exposed by Snowden, is probably one of the biggest programmes collecting data of foreign and domestic citizens in the world. However, as terrorism has already existed before the 21st century, also counter-terrorist measures have a long tradition (Bigo, D., 2006). The method of collecting data by using computerized systems has its beginnings in the second half of the 20th century. This new "computational security" is widely regarded as the beginning of "new surveillance" (Baumgärtel, 2013; Lyon, 2006, p.3; Marx, 2002, p.9; Katzenstein, 1993, p.162). One of the countries which first made use of new surveillance methods was West-Germany (in the following only referred to as "Germany"), having to deal with left-wing extremism in the 1970 s and 80 s. It is, therefore, of particular interest to investigate to what extent Germany could cope with the new challenges and keep its democratic legitimacy as a Rechtsstaat, in particular in view of its fragility as a young and politically divided democracy. The Rechtsstaat is here defined as "a state in which the rule of law prevails" (Heun, 2011, p.36).

This paper examines to what extent the new surveillance and security methods, introduced by the German government against the RAF, led to a transformation of the understanding of the Rechtsstaat. To elaborate on this question, the first part touches upon the evolvement of the RAF. Furthermore, it introduces the criminologist Horst Herold, the main "hunter" 
of the RAF in more detail, and the creation of dragnet investigation. The second part outlines the concept of new surveillance using literature by Gary Marx and David Lyon, and examines to what extent "new surveillance" theory can be linked to the events in Germany. The third part explores the workings of the legislative and executive powers of the time by illustrating how they were threatening to undermine the Rechtsstaat in the attempt to establish security. The paper concludes by arguing that to counter the radical left-wing movement of the 1970s and the RAF, the German government implemented a number of policies and new processes, which challenged some of the basic principles of the Rechtsstaat, and thereby jeopardized the political and judicial foundations of this young democracy (Frohman, 2015).

In terms of methodology this chapter is based on a qualitative analysis of primary sources, such as the German constitution and its subsequent interpretation, newspaper interviews with contemporary witnesses, and written pieces by important actors. Numerous secondary sources supplement the study with additional information on counter-measures and consequences for the Rechtsstaat. Gary Marx (2002) and David Lyon (2006, 2007) are two renowned surveillance scholars whose theories guide this chapter in its analysis and lay the foundation for the argument that security and surveillance methods pose a threat to the principles of the Rechsstaat.

In regard to the literature on left-wing terrorism in the $1970 \mathrm{~s}$ in Germany, judicial, political, sociological and autobiographical works predominate the field (Weinhauer, 2004). Beatrice de Graaf (2011), for example, analyses the effectiveness of counter terrorism measures by governments and generally argues that these measures do more harm to "law and order" than good. Wolfgang Kraushaar (2006) looks in particular at paragraph 34 StGB (state of emergency) in the context of the Stammheim trials and the Schleyer kidnapping in 1977. Even though there has been 
much written about certain parts of the 1970 s and its effects on society, there has not yet been an analysis focusing on the impact surveillance and security measures had on the Rechtsstaat.

Our angle to approach the anti-terrorism measures in Germany marks a novelty in this field as it pays particular attention to Marx's "new surveillance" theory. Furthermore, the perspective of "surveillance and security" studies has not yet been applied to this historical period. The aim of this paper is to combine a historical perspective with the theoretical framework set out by Marx and Lyon and to investigate whether there is a concrete link between the newly implemented surveillance methods, such as dragnet investigation, and the rethinking of the Rechtsstaat. To understand the full impact of "new surveillance" it is of vital importance to analyse and understand the origins of these methods, as this will help understand the overall development of surveillance practices. Therefore, Germany in the 1970 s is an ideal case for this analysis.

The struggle between the German state and left-wing terrorism presents an interesting example of power struggles in Western democracies in post Second World War politics. While the young democracy resorted to the instruments at hand, such as law enforcement, the RAF continuously tried to challenge the Rechtsstaat with increasingly violent and deadly attacks on institutions as well as on political and economic representatives. The government mobilised all police forces by centralizing them under the BKA and significantly increased the independence of a few leading figures of law enforcement. These measures stretched the limits of the Rechtsstaat to the extent that they started to face strong criticism and even constitutional court interference from the late 1970 s onwards. 


\subsection{Red Army Faction (RAF)}

The following section shortly describes the roots of the RAF and their motives to provide the substantial context of their actions. The origin of the militant left-wing movement lies in the frustration with the not very effective protest movement of the 1960s. The RAF founders came directly from the environment of the 1968 protest movement. Today, the group is considered as a result of the quick disintegration and change of the protest movement after the implementation of stronger police action against protesters (Kraushaar, 2006). The RAF's politically motivated struggle with the German Rechtsstaat focused particularly on the fight against capitalism and imperialism embedded in the, according to their view, German political system that had not successfully distanced itself from fascist tendencies (Bauer, 2011). In this regard, it is important to place the emergence of the RAF in its contemporary socio-political context.

An important role in this context is played by the difficulties of Germany's postwar generations to come to terms with the NS-past of their parents. In addition to that, the Vietnam War resulted in a general crisis of credibility of democratic regimes, which also affected Germany (ibid.). In one of their first publications the RAF considered itself as an "urban guerrilla" (Hoffmann, 1997, p. 40), and, hence, violence was regarded as a necessary means to, on the one hand, demonstrate emancipation and, on the other hand, counter the violence employed by the state. The left-wing journalist Ulrike Meinhof quickly became the main spokesperson and author of the group's publications, in which they declared war on the Federal Republic and its institutions. They wanted to provoke the German state to act against its own laws and, thus, expose the authoritarian state it was accused to be. The state lacked a concrete legal basis to counter the RAF's actions and was, therefore, not properly prepared to face such a challenge (Klink, 2011). With its revolutionary approach to attack the political, 
economic and legal structures of the state, the organization tried to overthrow the state, overturn society and establish a communist regime. Furthermore, it questioned the monopoly of the state as to the use of force and the legitimisation of the Rechtsstaat (Kraushaar, 2006). The most violent year constitutes 1977, with the assassination of state's attorney Buback, Deutsche Bank financier Ponto and the President of the German Employers Association Schleyer. The eventual break up of the group took place in 1998 after years of reduced or no attacks at all (Schleicher, 2011).

\subsection{Dragnet investigation}

The following section introduces Horst Herold and his initiated police reform, which coincided with new developments in the way prevention in social, environmental and criminal domains of the state was understood (Frohman, 2015). One of the results of his technology-oriented research and criminological studies is the method of dragnet investigation ${ }^{1}$. Herold's vision of reforming police work with the usage of the newest technology and, hence, new surveillance instruments for crime prevention helps to understand the subsequent responses of the government.

\subsubsection{Horst Herold's vision}

In the early 1960s in West Germany, thoughts concerning the change of the functioning of the police in society had often been expressed. At that time, the visionary federal prosecutor Horst Herold from Nurnberg recognized the potential of computers in regard to police work. Data is more useful the more it has the characteristic of facts and the less it is based on subjective

\footnotetext{
${ }^{1}$ In original language: Rasterfahndung
} 
observation such as witness reports, according to his opinion. This should help to strengthen transparency and objectivity in court, in form of clear and incontestable evidence. Herold recognized the weak points of police work before many others did (Albrecht, 1988).

The basic reasoning behind data processing was to include developments of society and, therefore, crime was considered as predictable and with the correct instrument even calculable. Herold was particularly influenced by the Marxist doctrine of the fixed and recognizable development of society. He aimed at structuring complex aspects of a case based on analytical thinking in order to apply rational measures. Herold believed that with the storage of criminologically important data a preventive and repressive evaluation of data would be possible. For him, prevention could be defined as the police initiated effort of all state bodies and of science to prevent crime (Albrecht, 1988).

Criminal geography, for example, investigates the relation between regions and crimes. Collecting electronic data about these connections would allow new research and, eventually, successful crime prevention. With the possibility of recognizing regularities in the offender's choice of object and crime scene, patterns could be noticed and, thus, enable the police to identify areas that posed a higher risk of crimes than others. The constant analytical and prognostic evaluation of data made it possible to recognize the changes and developments of different types of crime.Thus, highly effective and selective police operations were thought to be possible. This provided new opportunities for the uniformed police, which could to some extent be transformed into a crime prevention police. 


\subsubsection{Background and origins of dragnet investigation}

Herold's aim was to develop and reorganise the Bundeskriminalamt (BKA) and move it to the center of the German police with the help of electronic data processing. In his ten years at the BKA, he is said to have built it up to the best police in the world next to the FBI (Prantl, 2013). In his opinion, the police could benefit more from the already collected data by using computers and, thus, making German police bureaucracy transparent and allow every policeman to access the same information. The introduction of the database INPOL - a federal information system for all German Federal Land Police departments - enabled the central storage of information about criminals. Other governmental and non-governmental crime-related databases were added which allowed them to conduct research on how to prevent crimes effectively. This served as the basis for the development of dragnet investigation in the following years. Herold differentiated between "positive" and "negative" search criteria in dragnet investigation. The former describes filtered criteria by the police such as hair colour, height and figure of the presumed offender. The latter involves the erasure of all persons in the police investigation portfolio who are not considered to be potential offenders. It is called negative dragnet investigation since the method searches for criteria that the suspect cannot fulfil. For example, persons with fake names cannot apply for financial support by the state, be listed in police records, receive child support and own a vehicle (Hentschel \& Pötzl, 1986). Most famously, this method was applied in the case of the Schleyer kidnapping. The law enforcement agencies had found out that all the appartments used by RAF members shared similar characteristics. They deduced certain personal traits from this, which they handed out to every police station in Germany. Based on this picture of typical terrorist behaviour, the BKA created an algorithm that looked for addresses with good transport connections to highways, high-rise buildings that offer 
anonymity, and payment details of electricity bills that were paid in cash and under false name since the terrorists could not open a bank account (Canos Panos, 2003). The BKA applied this search pattern on a radius of $15 \mathrm{~km}$ around the crime scene. Filtered appartments were checked with customer details of electricity plants and this information was compared with names in civil registers and insurance data in order to select suspects (Biermann, 2013).

\subsection{New Surveillance, security and its beginnings in West Germany}

It is generally accepted that a fundamental change in surveillance occurred in the second half of the 20th century. In 1988 Marx (2002) was the first to describe "new surveillance" (p.9). The unresolved question remained however, what innovative features characterize this "new surveillance" and why they constitute a fundamental change in comparison to previous forms of surveillance? Did new technologies also change practices? Marx (2002) argues that this is not the case, meanwhile Lyon (2006) emphasises that "while surveillance practices are as old as human history, they took some rather specific forms in the modern world, becoming routine and systematic, based especially on individuation and on bureaucratic organization" (p. 3). In the same way Didier Bigo (2006) states that "surveillance technologies, as well as attitudes towards constant monitoring of activities, have shifted and greatly expanded to become routines of everyday life" (p.46).

Marx (2005) distinguishes between traditional and new surveillance. Traditional surveillance can be defined as "close observation, especially of a suspected person" (ibid.). For contemporary forms of surveillance, starting in the second half of the 20th century, this definition is no longer applicable. Marx holds that the nature of the verb "observe" in the old definition has fundamentally changed, as modern surveillance methods heavily rely on 
technical means, which go beyond traditional forms of keeping an eye on a suspect. He defines "new surveillance" as "scrutiny through the use of technical means to extract or create personal or group data, whether from individuals or contexts" (ibid.). An obvious important new element in the definition is the emphasis on "technical means". Additionally, the new definition dropped the verb "observe" and replaced it by "extract or create" data, thereby referring to the collection of mass data. The last part of the definition also gives insight into the changes of surveillance methods. Data can now be extracted or created from "individuals or contexts".

Contemporary forms of surveillance can transcend "natural and constructed barriers" (Marx, 2002, p.9). By natural and constructed barriers Marx means distance or darkness (natural) and walls or fences (constructed). He argues that new forms of surveillance, in most cases, do not target a specific person anymore. Surveillance methods are used categorically and in different contexts. Specifically, various geographical places, particular time periods, and targeted categories of people are being subjected to surveillance (ibid., p.10). The old distinction between an agent observing a target, therefore, does not hold in times of mass data collection. With the help of new technological means agencies can go "beyond unaided senses" (ibid., p.15). In other words, with the help of microphones or cameras agencies can record conversations or people, which they could not have done without new forms of technology. Technology has had a logical impact that caused drastic changes in the very form surveillance is being approached. In contrast to targeting a specific suspect as starting point of an investigation, surveillance has become a means to find a suspect among a much larger group in the population. Especially, the method of "profiling" gained popularity among security agencies (Bigo, 2006, p.49; Lyon, 2007, p.161). Even though Marx already examined these new surveillance methods 
in the 1980s, he never combined his research with an analysis of Germany in the 1970s. A gap in academia this chapter fills.

When Horst Herold took office in 1971 he started implementing "new surveillance" methods in the BKA. The controversial implementation of the dragnet investigation is a prime example of the beginnings of "new surveillance". Interestingly, Baumgärtel (2013) argues that contemporary methods used by the American National Security Agency (NSA) and British Government Communication Headquarters (GCHQ) are based on Horst Herold's ideas. When Herold set out to centralise the German policing system he made use of the newest technology at hand. By computerizing all information he started the process of collecting mass data. For our chapter it is important to ask whether Herold's new methods fit in with the definition of "new surveillance" mentioned above. On the one hand, the police had developed an idea as to who the suspects were. On the other, the newly implemented methods comply with other elements in Marx' definition. Firstly, it stipulates the use of "technical means" in order to overcome limitations of the "unaided senses" (Marx, 2002, p.12). Dragnet investigations are not conceivable without "technical means" as computers crawling through mass data to find particular people, such as those who paid their rent in cash. Secondly, the new methods intended to extract data by computer profiling and also created data, by deciding which characteristics the computers were to be looking for. All the information concerning the RAF first had to be compiled from scratch, i.e. specific criteria had to be established. Renting a flat under a false name, paying bills in cash, short distance between flats and highways, young, single, no car, receiving little mail and other criteria were established. In this way a terrorist profile was created, which - of course - also fit ordinary citizens. By definition the dragnet investigation included a lot of "bycatch". 
The counter-terrorist measures caused a "generalized state of exception", as Bigo (2006) calls it, which demanded huge resources (p.49). It has been calculated that in the 1970s, of all criminal acts, "terrorist attacks and violent demonstrations accounted for $1 \%$ of all recorded criminal acts" (Katzenstein, 1993, p.161). The police force involved in counter terrorist investigations, constituted up to 10 percent of the whole police force (ibid.). The 1970s also witnessed a quantitative expansion of the police force as a whole. These developments contributed to blurring the line between normality and emergency (p.162). The generalized state of exception has also been intensively examined in the aftermaths of $9 / 11$, which in this perspective was hardly an "unprecedented event" (Bigo, p. 50). Hijacking planes or bombings of specific locations or buildings have happened before, for example in West Germany (ibid.). The feeling of unease can lead to panoptic surveillance of and by everyone which can lead to a "generalized state of exception" and new methods of finding criminals or terrorists, which is an important aspect of "new surveillance" (ibid.).

Therefore, many scholars (Bigo, Ball \& Haggerty, 2012; Feldman, 2011) argue, the line between security studies and surveillance studies is blurring, as each may start at different points but in essence deals with the same issues. Both academic fields tried to focus on the newly implemented counter-terrorist measures erupting in Europe and other countries (p.278). The most crucial link between the two academic fields, which again shows their interconnectedness, is the "obsession with the preventive dimension" (p.283). It is the aim to counter future attacks on the state and this has led to the belief that using computers and databases, can actually monitor and control future activities, as exemplified by Herold's own visions. The development of "new surveillance", as described by Lyon (2006), Marx (2005) and Bigo (2006), must be seen in relation to the newly developed 
MaRBLE Research Papers | Edition 2016 | Volume III

field of security studies as both are deeply interlinked, as will also be shown in this chapter.

\subsection{The RAF's impact on the German state and society}

\subsubsection{Counter-measures taken to combat terror threat}

In order to present an overview of the scope and nature of responses by police and government in the 1970s, this section outlines general counterterrorism measures that contributed to the fight against the RAF. The German government took a number of measures to restore order and guarantee internal security. This led to a general restructuring of the security architecture and assignment of competences (Hanshew, 2010).

With the emphasis on geographical-criminal areas, the BKA aimed at arresting suspects to prevent future crimes and attacks. When Herold became the head of the BKA, regional investigations and special search groups were organized as well as the general introduction of more technological tools. The establishment of the department for data processing (today: information technology) laid the basis for criminological evaluation of information (BKA Historie, n.d.). The BKA steered the regional special committees' activities and evaluated the information they gathered. Soon the amount of data became so extensive that Herold began to store it on central computers, which also speeded up the process of evaluating the data. The outcome would then be transferred back to the regional stations. The new BKA-law of 1973 extended the competencies of the Federal Police by positioning the office as the information and communication centre of German police (BKA Historie, n.d.). These technological developments introduced a new phase in police work that enabled the police to process more information and analyse it more effectively. 
One of the most controversial actions taken by the government was the implementation of the Decree of Radicals (Radikalenerlass) in 1972. It served to make sure that newly recruited civil servants shared the government's democratic values and did not come from a radicalised environment. Hence, the Federal Office investigated every applicant for his or her adherence to the Constitution. The Schleyer kidnapping generated even more severe measures (Hanshew, 2010). Firstly, the Contact Ban Law allowed federal and state justice ministers to forbid prisoners to communicate between each other and the outside world in case a "present danger of life, limb or liberty" was strongly presumed (Sobieck, 1990, p. 55). Secondly, the crisis management group, which was created during the hostage-taking of the German embassy in Stockholm, was reinstalled to deal with the Schleyer case. Already in 1975, in the aftermath of the hostagetaking of Stockholm, chancellor Schmidt had stated that "if you want to reliably protect the Rechtsstaat, you yourself have to be ready to push the Rechtsstaat to its limits"2 (Historische Debatten (8): Kontaktsperregesetz, n.d.). For 44 days, the crisis management group executed the governmental power of the nation. Thirdly, a news blackout was introduced for the whole duration of the Schleyer kidnapping. This self-censorship of the media was based on an agreement between the media (newspaper, radio and tv) to not publish any information on the status of police investigation without consulting the BKA beforehand (Kraushaar, 2007a).

The German Autumn of 1977 highlighted the RAF's capabilities and challenged German security authorities to an even larger extent than before. Hunger strikes, hostage-taking to release prisoners in return and the politicisation of criminal proceedings put a lot of pressure on the authorities.

\footnotetext{
${ }^{2}$ Original quote: "Wer den Rechtsstaat zuverlässig schützen will, der muss innerlich auch bereit sein, bis an die Grenzen dessen zu gehen, was im Rechststaat erlaubt ist".
} 
As a response, the BKA intensified the manhunt for the sixteen top RAF terrorists with a new special committee. The focus shifted more towards terrorists who had gone underground and to tracing their logistical bases. The search was enlarged to Western Europe and made use of the dragnet investigation method (Schleicher, 2011). In the following parts of the paper these policies are discussed in greater detail, emphasizing its implication for the workings of the Rechtsstaat [or summarize the main aim of the section in another way].

\subsubsection{Political actions and their consequences for the Rechtsstaat}

The constitutional debates in 1948-1949 between Social Democrats and conservatives show how the SPD pictured the role of the state and balance of power. They advanced the view that true democracy is only possible with active citizens. Thus, in case of a severe crisis, no measure by the government could protect democracy if its citizens had already given up on it. The party concluded that it was necessary to provide protection from the government as well as from the population within the legal framework. The authors of the constitution expected most danger to democracy to emerge at the local level. The state, however, presented a neutral instrument depending on who held its power. Therefore, providing security would be only possible with the regulation of institutions in the democratic state (Hanshew, 2010; Born, 2011).

Between 1949 and the late 1960s, the country was governed by conservatives and strongly shaped by the policies of Konrad Adenauer (in office from 1949 to 1963). He paved the way for remilitarization and NATO membership. At the same time, an extra-parliamentary left-wing movement had emerged and attracted popular support. From 1969 onwards, Willy Brandt's administration (SPD) focused on a program of inner reform 
promoting new forms of democratization. The government gave the extraparliamentary opposition regulated legal room in order to channel the emerging protest generation's concern with the Vietnam War. In addition, with the introduction of new management techniques and computer technologies, the government hoped to remove inefficient working processes at the local and regional government level. In general, technology was considered as an efficient and economic instrument that could only positively impact decision-making (Hanshew, 2010).

As the RAF grew stronger the need for a modernization and centralization of the federal police increased. Herold, himself a social democrat, was generally supported by the SPD. Advanced technology was seen as an instrument to prevent abuse of power (Hanshew, 2010). However, the government was soon pushed to widen the boundaries they had set earlier to prevent an abuse of power (ibid.).

\section{Rasterfahndung}

As long as the measures following from dragnet investigation were successful, Herold and his staff did not meet much criticism. Yet, this changed in 1977 (Weinhauer, 2004). Since there was no real legal basis for dragnet investigation, police and government referred to extra-statutory necessity as they did with other police methods that could be considered as constitutionally questionable (Gusy, 2007). Even though Herold had brought most of the first generation of the RAF behind bars, his method faced growing concern over the surveillance of innocent people's private lives, in particular in the aftermath of the Schleyer kidnapping. The power of the police had significantly grown since Herold took office and increased the budget as well as staff numbers. These vast state expenditures were the 
result of pressure on the government to prove that the state is better prepared to guarantee order and security than its predecessor of Weimar.

The German Autumn constitutes the beginning of a change of political and societal tendency.Until then the constant extension of surveillance, control and data collection methods did not face much resistance although it was often undertaken without political approval (Weinhauer, 2004). In 1978, a different political direction was chosen with the new Interior Minister Baum who started to limit the scope of data processing and the BKA's wide reaching competencies. This can be placed in the context of emerging criticism towards the BKA in the aftermath of the Schleyer kidnapping because of mistakes that were made during the search. The media started to analyse domestic politics more sceptical and, thus, intensified growing public criticism. In the early 1980s, people feared the development of a surveillance state as described by Orwell. Rising critical awareness of problems and limits of electronic data processing can be observed in surveys showing that in 1975 up to $69 \%$ of interviewees accepted restrictions in civil liberties in the name of combatting terrorism. However, in 1978 this had already decreased to $53 \%$ (ibid., p. 239). Thus, data protection had become a popular topic in politics which was increasingly considered as an important task performed by the state. In general, the fear of misuse of personal information rose slowly but surely. Terrorism and its countermeasures had become more tangible for the population in form of local policemen in neighbourhoods, traffic control due to the search for suspects and the political background check in the context of the employment in the civil service (Weinhauer, 2004). 


\section{Electronic eavesdropping and the Decree of Radicals}

An additional method of the police involved wiretapping operations, most famously the scandal concerning nuclear scientist Klaus Traube which eventually led to the resignation of Interior Minister Werner Maihofer (Kraushaar, 2007a). Another example presents the case when legal defender of the RAF member Gudrun Ensslin accused the Federal Office for the Protection of the Constitution of listening to conversations between the defender and his clients. These accusations proved to be true and resulted in another political scandal. Der Spiegel investigated the Stammheimer Lauschangriffe (Stammheim's wiretapping operations) and concluded that security institutions conducted wiretapping operations on a grand scale to combat terrorism. For example, telephone conservations of attorneys and doctors of RAF terrorists were tapped in the hope to receive clues on their location. Here, Marx's definition of "new surveillance" applies since electronic eavesdropping enables security authorities to observe persons of interest without being physically present and, therefore, overcome natural and constructed barriers.

The highly discussed Decree of Radicals serves as another illustration. The thorough background check and investigation of potential civil servants on the basis of their political suitability was supposed to prevent members of the German Communist Party, among others, to enter public service. However, the majority of the protest generation complained to be affected by this occupational ban, as its critics called it. Until the late 1980s, 3.5 million applicants for civil service were investigated and 10.000 named ineligible. Therefore, a debate on the decree's constitutionality was initiated. Yet, it took several years for the decree to be annulled (Hofmann, 2013). 


\section{Blitzgesetze}

The legislature contributed significantly to the state's ability to quick decision-making and effective counter-measures when facing the danger of instability and immediate terrorist threats.

Since the Republic experienced certain situations caused by the RAF for the first time, such as the politicisation of trials, legal gaps confronted the Rechtsstaat with challenges. Hence, the government passed several bills in a short time to address these loopholes in the law which were called Blitzgesetze. Arguably, they represent the strongest indication for the state of emergency at that time. Within four years, six new laws with 27 restrictions on the rights of the defendants were passed, often just within days. Furthermore, these laws mostly presented facilitation for the work of prosecutors. In the preparations for the Stammheim trials in 1975, several amendments were passed, such as the prohibition of the right to multiple defence and the possibility to proceed with a trial without the presence of the defendant (Wesel, 2007). The peak of suspiciousness was reached with more and more decrees against defenders on the basis of safeguarding the reputation of the legal profession. It became public that the conversations between defenders and their clients were tapped and these recordings were transferred to security authorities. In the case of the Contact Ban Law, such a quick passing of the bill was only possible because it was introduced as an inter-factional bill. Otherwise it would have taken more than just a couple of days to pass the bill (Historische Debatten (8): Kontaktsperregesetz, n.d.). Overall, these new provisions demonstrated the repressive tendency of the state and its unreadiness for political and constitutional challenges in regard to terrorism (Wesel, 2007). 
Eventually, the generalisation of the not officially proclaimed state of emergency that served as a legitimate basis for all kinds of surveillance methods was caused by terrorism. Examples can be found in the surveillance of suspected RAF members, attorneys and doctors of known RAF terrorists as well as the listening to private conversations within the prison. An even broader scope of innocent citizens was affected by nationwide measures as for instance dragnet investigation which involved a significant amount of personal information of millions of citizens. A strong link between the need for security and surveillance becomes apparent starting in the early 1970 s (Bigo, 2006; Feldman, 2011). In the beginning of the implementation of restrictive counter-measures, people accepted the restrictions of their individual rights in exchange for order and stability as the RAF was successful in spreading fear with its violent actions. During this time, certain surveillance measures became a routine for citizens such as the checking of personal information in the context of dragnet investigations. This clearly illustrates the blurring between normality and state of emergency in the German Rechtsstaat. As long as the measures could be clearly linked to the search for wanted terrorists, it seemed that citizens tended to accept these circumstances. Yet, measures such as the Decree of Radicals which asked for a thorough political background check of each civil servant applicant met severe outrage among citizens. At the latest in the period following the German Autumn, a break with previously accepted measures can be recognized. The government increasingly came under pressure to explain its actions and failures.

\subsection{Conclusion}

In this chapter we have shown what impact the actions of the RAF in the 1970s had on Germany's Rechtsstaat. Whether one sees the political 
measures and reactions as a success (Mückl, 2007; Miller, 2010) or as a failure (Kraushaar, 2007a; De Graaf, 2011; Katzenstein, 1993), we argue that this period put the young democracy to a comprehensive test. Our claim is that the implementation of new surveillance and security methods, introduced to counter the RAF, markedly undermined the Rechtsstaat. This is exemplified by the authorities making extensive use of the "state of emergency", changing political processes and curtailing fundamental liberties. Some of these changes were permanent, other policies were abandoned again, such as the Decree of Radicals. Many of the changes, whether permanent or temporary, were of questionable legality.

The paper began by providing a background to the history of the RAF and introducing the inventor of the dragnet investigation, Horst Herold, who can be seen as one of the pioneers of "new surveillance". In his view, profiling and computer based surveillance was necessary to protect the wider public and the foundations of the state. His ideas fit in with the ruling by the federal constitutional court of 1968 , in which it clearly positioned itself as supporting the concept of a "wehrhafte Demokratie" (Miller, 2010). Herold was the head of the German police for ten years and modernised it to such a degree that it was regarded the best police department next to the FBI. However, many regard Herold's policing methods as the beginning of computer profiling, which led to thousands, if not millions, of innocent citizens to be included in large databases. The aim of the RAF was to unmask the Federal Republic of Germany for what it, in their view, really was, a fascist and imperialist system. Motivated by the failure of the 1968 movements the RAF and other left-wing radicals' saw a loss of credibility of democracies.This view was strengthened by the way the West dealt with the Vietnam War. Here, the RAF saw itself as an "urban guerrilla".

The RAF was a terrorist organization and had to be treated accordingly, however, as De Graaf (2011) has pointed out, most counter- 
terrorist measures are still in some form active today and, thus, outlived the terrorists that provoked them. Therefore, as this paper has shown, the 1970s have led to a shift in the perception of the Rechtsstaat as the boundaries of what is legally permitted were extended. The RAF, thus, led to an "unmasking" of the German state, however, to a different degree than they had intended. When the actions of the RAF were at their height, the organization had some support among the Germany population, which is an indicator for a general atmosphere of suspicion towards the state.

The debate about the potential clash between individual liberties and security of the state, which dominated the 1970s, has had profound repercussions ever since. Using the ideas of Bigo $(2006 ; 2012)$ it was shown that the justification and legitimization of new legislation always referred to a necessity in a "state of exception". However, as Bigo has stated, such repetitive usage of arguments concerning a "state of exception" leads to a "general state of exception" (ibid.). This is exactly what happened in West Germany at the time. One of the main aspects of surveillance and security studies is the "preventive dimension" (Bigo, 2012). It is the aim of the state to catch criminals before they commit the crime. However, as it is illegal to detain any citizen for not having done anything illegal, new laws were introduced to ease this process. One of them prohibited mere membership of a terrorist organization, for example. These laws were clearly led by a preventive approach, and thereby fit in with the ideas of surveillance and security studies (Frohman, 2015). The concept of "new surveillance", introduced by Marx (1988) and extended by Lyon (2006) is applicable to the developments of the 1970s. The analytical framework of surveillance and security studies helps to shed light on these events. Particularly, their focus on the compatibility of the Rechtsstaat and counter-terrorist measures is helpful in this context. This paper has shown an inherent link between surveillance and security measures and the infringement of citizens' liberties. 
All measurements taken by the German government were subjected to criticism in the aftermath of the events, with many questioning their legality and necessity.

The RAF had set out to challenge the German state and show its true colours. They saw in the majority of the political elite the remains of the fascist state as several important personalities in politics and economy used to be part of higher ranks in the Nazi regime. Questions concerning the right-wing legacy and demands for a proper process in coming to terms with Germany's past were presented by leftist orientated parts of society but should not be fully heard until more recent years. Claims that the republic was blind on its "right eye" found some confirmation with the Oktoberfest bomb attack by a right wing extremist in 1980 and, most notably, with the NSU scandal in 2011. There will always be those challenging and attacking the state's structure. The 1970s in Germany have proven that countering those attacks may be as difficult as fighting the state as a terrorist. Some argue the government and police overstepped the lines drawn by the constitution, others argue the state acted within those lines. The claim of this chapter is that, regardless of the legality of specific laws, many processes, policies and procedural changes were of questionable necessity and legitimacy.

This chapter shows that counter-terrorist measures must be implemented in a very cautious way and that it is important, for the government, to stay within the boundaries set by the Rechtsstaat; otherwise, the claims by the terrorists are supported and strengthened by the state.

The key strength of this chapter constitutes its unique approach to look at Germany's counter-terrorism measures on the basis of Marx's "new surveillance" theory. As a consequence, this chapter adds the perspective of 
surveillance and security studies to a topic that is dominated by historical literature. Furthermore, this approach also taps into the broader relevanceof our contribution. Whereas the RAF terror threat is to some extent still remembered by a majority of German citizens today, the surveillance methods that were adopted at the time have not been thoroughly discussed and accepted. In the context of the recent NSA scandal, the methods of the 1970s shed an interesting light on the German Rechtsstaat's evolution and raises the question as to whether something has changed since then. The latter would present an interesting angle for further research with a stronger link to current events in matters of national security.

[2] Original language: "Übergesetzlicher Notstand". 